\title{
The influence of hydrogen addition for exhaust gas emission in SI gas engine
}

\author{
JEL: Q01 DOI: 10.24136/atest.2019.043 \\ Data zgłoszenia: 15.12.2018 Data akceptacji: 08.02.2019
}

One of the major problems in internal combustion engines is emission of pollutans with exhaust gases. Those pollutants are not only harmeful for enviroment but also for humans. To decrease emmision of polu-tants many mechanical and chemical methodes are used in internal combustion engines especially in exhaust system such as TWC, DPF, SCR. Alternative way for decrease in exhaust gas pollutants is use of alternative fuel as a primary energy carier or as an additional fuel for base hydrocarbon one. In this studies the hydrogen was used as a additional fuel to methane. Both fuels were delivered to intake mani-fold. The share of the fuel was 100/0 methane/hydrogen and 70/30 methane/hydrogen. The addition of hydrogen to base fuel shown decreas of exhaust pollutants from engine and inrease in engine operating parameters.

Key words: Sl engine, hydrogen, methane, emisisons.

\section{Introduction}

One of the problems which is releated with human activity is increase in emission of pollutants. Those pollutants are not only harme-full for envirokent but also for humans. After industrial revolution the increase in $\mathrm{CO}_{2}$ emission from fosil fuels increase almost from 0 to 35 billion of tones [10]. From that reason the goverments of different con-tries as well as EU are very strict with limiation of emission of pollu-tanst. One of the source of those pollutants are means of transport which are equipped with internal combustion engines. There are several methodes to decrease emission of polutants from IC engine. Nowaday for that purpouse there are use three way catatlitic convert-ers (TWC), selective catalitic reactors (SRC) and diesel particalte filter (DPF). The aim of this methodes is to decrease emission of such exhaust gas components as nitrooxides $\left(\mathrm{NO}_{\mathrm{x}}\right)$, carbon dioxide $\left(\mathrm{CO}_{2}\right)$, carbon monooxide $(\mathrm{CO})$, unburned hydrocarbons $(\mathrm{HC})$. Except does filtering methodes for reduction of polutants from exhaust gases, there are other options. One of another opsion is to use fuel with less car-bon in it. That mean that the hydrogen to carbon ratio $(\mathrm{H} / \mathrm{C})$ should be greater than for typical hydrocarbone fuel. Such alternative fuel which can be used is hydrogen.

It can be siad that hydrogen is the cleanest fuel regarding $\mathrm{CO}$, $\mathrm{CO}_{2}$ and $\mathrm{HC}$ emissions, it should decrease the emissions [6]. The product of hydrogen combustion is only water. Beside those properties hydrogen has other which can bring another advantages to IC engine, among other are minmimal ignition energy, laminar flame speed, explosion limits. The comparation of the hydrogen, methane and gasolin properties are presented in table 1.
Tab. 1. Fuel properties $[1,7]$

\begin{tabular}{|l|l|l|l|}
\hline \hline Phisical properties & Hydrogen & Methane & Gasoline \\
\hline Density (kg/m3) & 0,081 & 0,657 & 720 \\
\hline Stoichiometric constant & 34,79 & 17,17 & 14,7 \\
\hline Heat of combustion (MJ/kg) & 141,7 & 55,6 & 46,4 \\
\hline Heat of combustion (MJ/dm3) & 0,011 & 0,037 & 33,4 \\
\hline Heating value (MJ/kg) & 119,7 & 37,71 & 42 \\
\hline Heating value (MJ/m3) & 0,01 & 0,025 & 30,24 \\
\hline Minimal ignition energy (mJ) & 0,02 & 0,28 & 0,25 \\
\hline Laminar flame speed (m/s) & 1,9 & 0,38 & $0,37-0,42$ \\
\hline Auto-ignition temperature (K) & 858 & 813 & 550 \\
\hline Explosion limits $(\%)$ & $4-75$ & $5-15$ & $1,1-6$ \\
\hline Explosion limits $(\lambda)$ & $10-0,14$ & $2-0,6$ & $1,51-0,26$ \\
\hline
\end{tabular}

The hydrogen has four times higher laminar flame speed compared to methane or gasoline, becouse of that the ignition timing for such engine shoud be tuned. Wider combustion limits allow for combust very lean mixture what has influence on exhaust gas emission. Those propertis allow to increase in engine indicated parameters such as efficiency. Kahraman et al. performed tests at spark ignited four cylinder engine fueled with hydrogen. The test resaults shows that hydrogen caused decrease in all pollutant [5]. The same results achieved Changwei and Shuofeng during their researche where the fuel which was combust was a mixture of gasoline and hydrogen with proportion of $0 \%, 3 \%$ and $6 \%$ by volume. For stoichimetric mixture the emission of $\mathrm{NO}_{\mathrm{x}}$ was the highest for $6 \%$ share of hydrogen what is related with temperatur of combustion for the mixture, but for lean mixtures the decrease of all polutants was observed [2].

Hydrogen has unfortanetlly several disadvantages which can cause faster demage of the engine in some unfavorable conditions. Such condition is knock combustion [3,9]. Becouse of low value of minimum ignition energy hydrogen can easly achieved autoignition. But that disadvantage can be controled with use of several methodes. One of the methodes is decrease of maximum temperatur of combus-tion. That can be achieved by use of over-expanded cycle what de-scribe Grab-Rogalinski and Szawaja [4] at theire work. Another methode for decreas the maximum temperature of combustion is use of EGR (Exhaust Gas Recirculation), such research was done by Nande et al. where he pointed the influence of EGR for reduction of knock combustion and $\mathrm{NO}_{\mathrm{x}}$ emission [8].

\section{Test bed description}

Test bed used during the research was equiped with single cylin-der variable compression ratio spark ignited engine. The change in com-pression ratio is done by changing the possition of cylinder head. The engine was modified to use gaseous fuel. The additional modification was made in ignition system instead of mechanical ignition system the engine use an electronic ignition system. The data of the engine are presented in table 2. 
Tab. 2. Parameters of the research engine

\begin{tabular}{|c|c|}
\hline \hline Cylinder no (-) & 1 \\
\hline Compression Ratio (-) & $4: 1-18: 1$ \\
\hline Bore $(\mathrm{mm})$ & 82,55 \\
\hline Stroke $(\mathrm{mm})$ & 115 \\
\hline $\begin{array}{c}\text { Displacement vol- } \\
\text { ume }\left(\mathrm{dm}^{3}\right)\end{array}$ & 0,615 \\
\hline rpm (min-1) & $600-1000$ \\
\hline Engine cooling system & Water cooled \\
\hline
\end{tabular}

The engine is coupled with asynchronous motor which is use as an starter for the combustion engine or as an generetor to provide the load for the engine. The asynchronouse motor is controlled by frequency converter. The engine can be fuelled both liquid or gaseous fuels. Gaseous fuel are deliverd to the intake manifold close to the intake valve by gas mixer. Liquid fuel is provided by injector mounted in itake manifold. There is possibility to mix several gases in certaine proportion. The proportion of the gas can be set with use of the gas folwmeters. The flow meters are set between gas tank and mixing device. The flow of gas fuel is regulated with use of precise needle valve which is placed before flowmeter. The scheme of test bed is presented in figure 1. The overview of the test bed is presented in figure 2 .

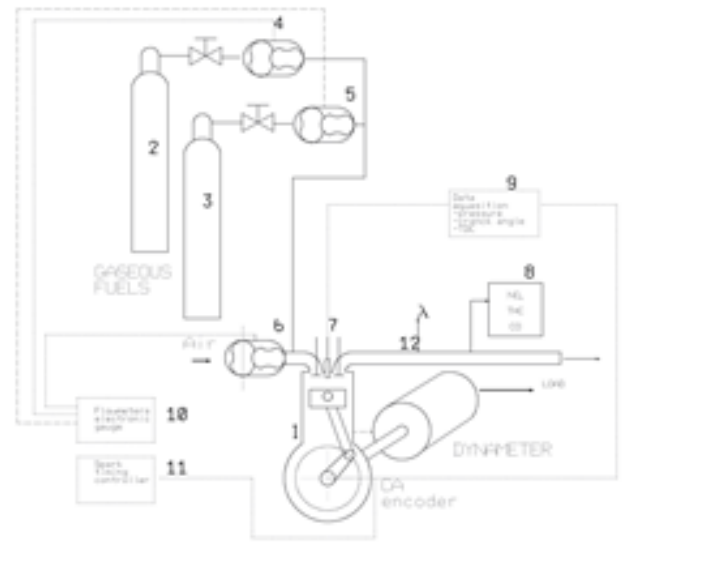

Fig. 1. Test bed diagram; 1-engine with generator, 2-hydrogen flask, 3-methane flask, 4-hydrogen flowmeter, 5-methane flowmeter, 6-air flowmeter, 7-pressure sensor, 8- bosch gas analyzer, 9-data acquisition systen, 10 -flowmeters electronic gauge, 11 -ignition control unit, 12-wide band oxygen sensor

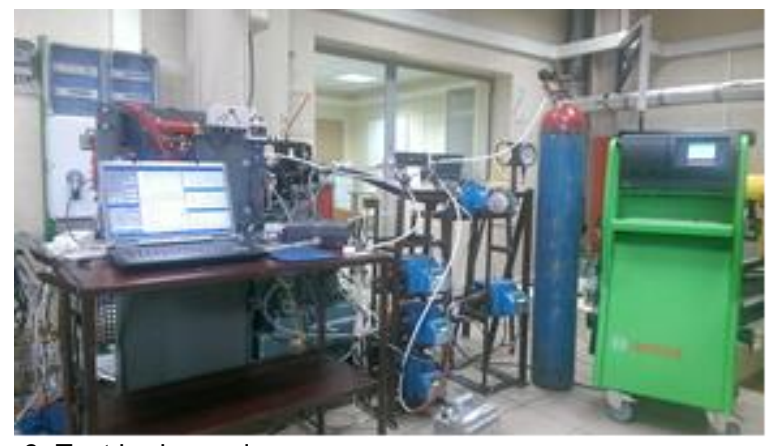

Fig. 2. Test bed overview

The test bed is equiped with measurement system which allows to monitor such parameters as: incylinder pressure, temperature of the engine, temperature of the fresh air or charge and temperature of the exhaust gases. For measure of cranck angle and position of top dead center (TDC) encoder was use wihich was mounted on camshaft. Flowmeters are equiped with electronic counters which present the actual value of flow for use gases. For measuring of excess air ratio wide band oxygen sensor was used. Additionally excess air ratio was measured on the exhaust gas analyzer. The pressure sensor and charge amplifier was manufacture by Kistler. Flowmeters CGR-1 were made by Common. Wide band oxygen sensor was made by Bosch. The encoder was made by Hohner. The parameters of the sensors used during the tests are presented in table 3.

Tab. 3. The parameters of the sensors

\begin{tabular}{|l|l|}
\hline \hline Sensor & Measurement range \\
\hline Pressure sensor KISTLER 6041B & $0-250$ bar \\
\hline Flow meter (Air) Common CGR-01 & $0,6-65 \mathrm{~m}^{3} / \mathrm{h}$ \\
\hline Flow meter $\left(\mathrm{CH}_{4}\right)$ Common CGR-01 & $0,25-25 \mathrm{~m}^{3} / \mathrm{h}$ \\
\hline Flow meter $\left(\mathrm{H}_{2}\right)$ Common CGR-01 & $0,5-25 \mathrm{~m}^{3} / \mathrm{h}$ \\
\hline Encoder Hohner PR90-23C1C-C & $1-65536$ \\
\hline Wide band oxygen sensor BOSCH LSU 4.2 & $9,56 \mathrm{AFR}(0,65 \lambda)-\infty$ \\
\hline Bosch BA250 exhaust gas analyzer & $\mathrm{CO} 0,00-10,00 \%$ vol. \\
& $\mathrm{HC} 0-9999 \mathrm{ppm}$ vol. \\
& $\mathrm{CO} 20,00-20,00 \%$ vol. \\
& $\mathrm{O}_{2} 0,00-22,00 \%$ vul. \\
& $\mathrm{NO} 0,00-5000 \mathrm{ppm}$ vol. \\
& $\lambda 0,500-9,999$ \\
\hline
\end{tabular}

Complete measurement system was connected to data acquisition system made by Measurements Computing The sampling rate of data card was $250 \mathrm{kS} / \mathrm{s}$. The card has 8 analog inputs, which allow to recorde signals provided by sensors. In this researche the signals which were connected to data aquistion system were: incylinder pres-sure, cranck angle and position of TDC. From data aqisition system the data were transferred to the PC where special program "SAWIR" calculated such parameters as: IMEP, rev, cumulative heat reales, ROHR, incylinder temperature, maximum incylinder pressure, cranck angle for maximum incylinder pressure, maximum pressure increase and cranck angle for maximum pressure increas, indicated power.

\section{Test procedures}

The tests of the engine were done in two phases. Before the test starts the volume share of gaseous fuels flow was determined. In case of this researche the two type of gaseouse fuels were use. First fuel was pure methane and the secound one was methane and hy-droge in a share of around $70 \%$ by vol. of methane and $30 \%$ by vol. of hydrogen. The calculation of the flows for gas fuels was done on a basis of the measurement of actual use of the air for the engine and declaration of the value of excess air ratio. Such approach for actual ambient pressure and temperature allowed to calculate flows which were close to the assumed values. After this calculations the precise setting of the gas flows were done on a basis of measurement of excess air ratio and flows for the fuels and air where engine was running. The measured value were use to calculate the percentage share by volume for the gases which were actually used. The excess air ration under which the test were done was $\lambda \approx 1\left(\mathrm{CH}_{4}\right.$ and $\left.\mathrm{CH}_{4} / \mathrm{H}_{2}\right)$ and $\lambda \approx 1,3$.

The first phase after settings for the fuel flows was to detrmine optimal ignition timing for the fuels with different excess air ratio. The determination was done by changing ignition timing in certaine range different for pure methane and for methane/hydrogen mixture. After determinatin the optimal ignition timing the measurment of exhaust gas emmision were done. The length of the test for each setting was 100 combustion cycle. The engine rpm was 850 $\mathrm{rev} / \mathrm{min}$. Operating temperature for the engine was $90^{\circ} \mathrm{C}$. The complete test matrix is presented in table 4. 
Tab. 4. Test matrix/Rodzaje pomiarów

\begin{tabular}{|c|c|c|c|c|}
\hline \hline & \multicolumn{2}{|c|}{ First phase } & \multicolumn{2}{c|}{ Secound phase } \\
\hline Fuel & $\mathrm{CH}_{4}$ & $\mathrm{CH}_{4} / \mathrm{H}_{2}$ & $\mathrm{CH}_{4}$ & $\mathrm{CH}_{4} / \mathrm{H}_{2}$ \\
\hline$\lambda$ & 1 & 1,3 & 1 & 1,3 \\
\hline $\begin{array}{c}\text { Ignition timing } \\
\text { range (CA) }\end{array}$ & $320-360$ & $320-360$ & 320 & 320 \\
\hline $\begin{array}{c}\text { Number of } \\
\text { cycles }\end{array}$ & 100 & 100 & 100 & 100 \\
\hline $\begin{array}{c}\text { Exhaust gas } \\
\text { emissions }\end{array}$ & No & No & Yes & Yes \\
\hline
\end{tabular}

The ignition timing was not differ for different combinations of gasoues fuels and for differen excess air ratio. This may be related with the fakt that the methane was main fuel. The results for determination of optimal ignition timing are presented in figure 3.

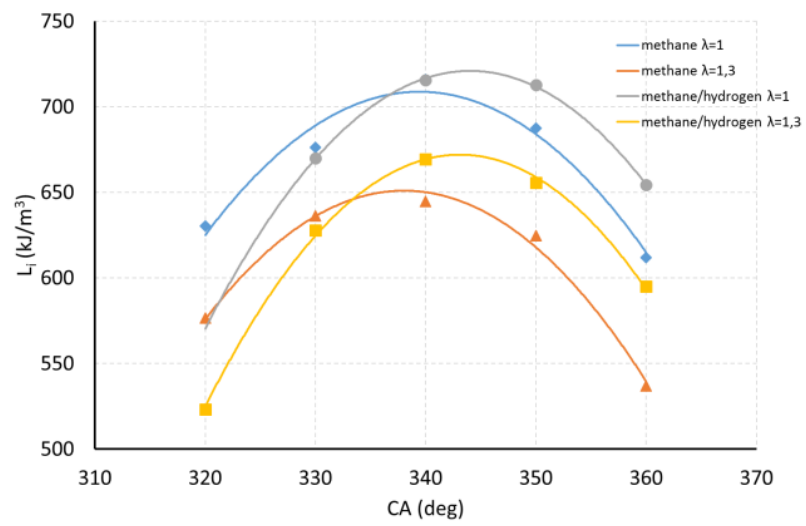

Fig. 3. Optimal ignition timing for tested fuels

As can be seen on the figure 3 the optimal timing for all fuels is arround 340 degrees of $\mathrm{CA}$, which means that the ignition advance is 20 degrees of CA bTDC. In case of fuels with hydrogen addition the ignition timing in both case of excess air ratio is closer than without hydrogen by 5 degrees of CA. The smaller value of ignition timing in that case is related with hydrogen laminar flame speed which is arounf four times higher than for mthane and othe hydrocarbon fuels.

\section{Results and discussion}

\subsection{Indicated parameters}

The measurements during the test were done for constant ignition timing in all cases. The chosen ignition timing was 340 degrees of CA (20 degrees of CA before TDC). Figure 4 present pressure vs. CA.

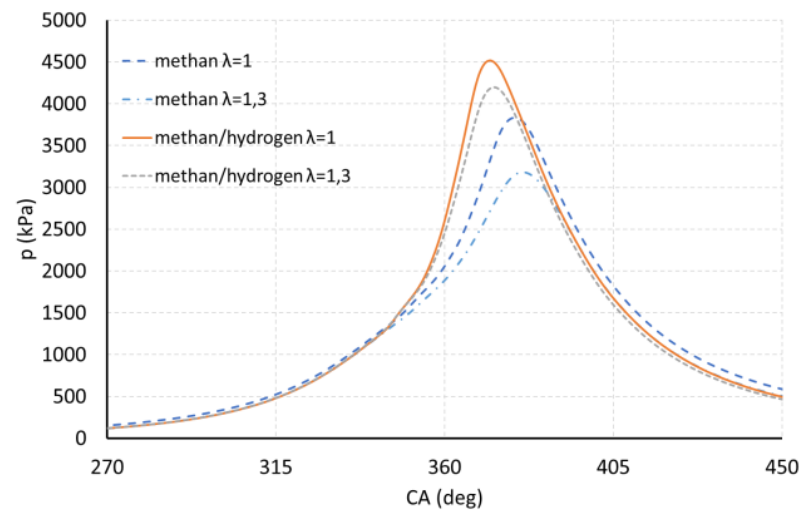

Fig. 4. Pressure vs. CA for tested fuels with different excess air ratio
As can be seen addition of hydrogen to base fuels in both cases of eccess air ratio couse increase in pressure. That increas is caused by laminar flame speed for hydrogen. This property allow to reach hinger value of pressure becouse the combustion last shorter than for hydrocarbon fuels and for first phase of combustion pressure increase is much higher. That can be seen in figure 5 , which presents the increase in pressure as a function of CA.

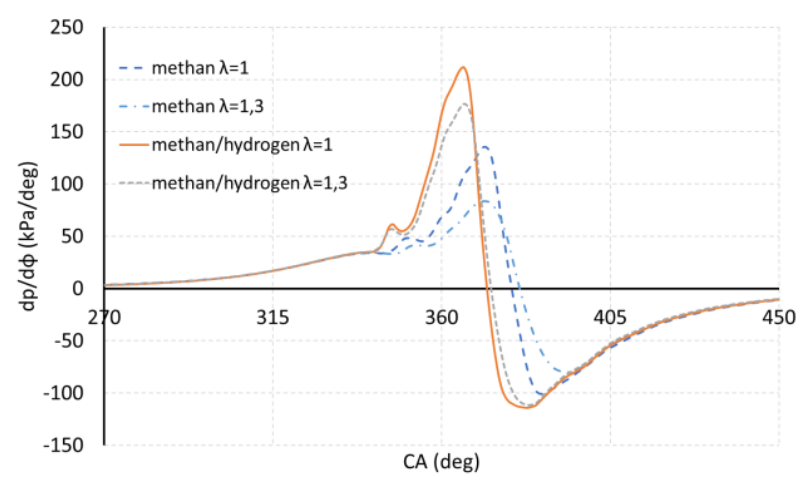

Fig. 5. Pressure increase vs. CA

The figure 5 shows that the trend with shortening the combustion is related with two factors first is excess air ratio in that case for pure methane the combustin duration for lean mixture is longer than for stoichiometric mixture. In mixture with the hydrogen the difference for the end of combustion is small. That can be observed in figure 6 .

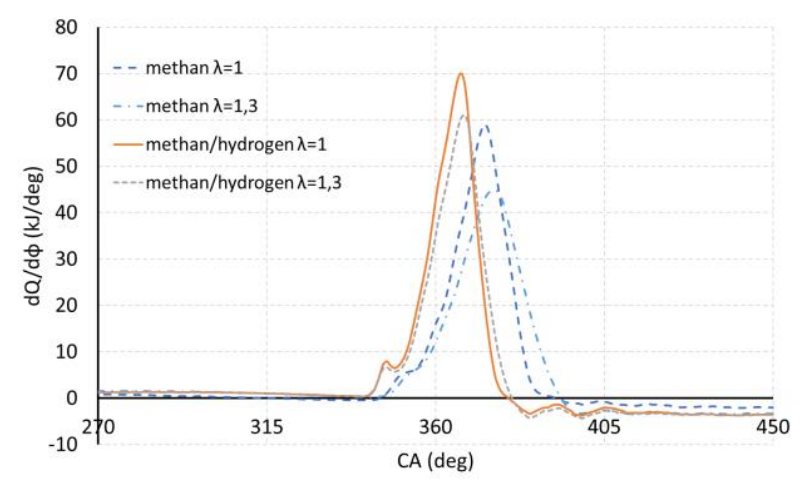

Fig. 6. Heat release rate vs. CA

As can be seen for mixtures which conatains hydrogen the heat release rate are higher than for pure methane. The heat release rate for methane with stoichiometric mixture is almost as high as for methane/hydrogen with lean mixture but the duration of combustion is longer for methane compared to methane/hydrogen mixture at different excess air ratio.

\section{Emissions}

During the test the exhaust gas emission was measured. The measured compounds of exhaust gas were $\mathrm{NO}, \mathrm{HC}, \mathrm{CO} 2$ and $\mathrm{CO} 2$. Figure 7 present emission of NO component. 


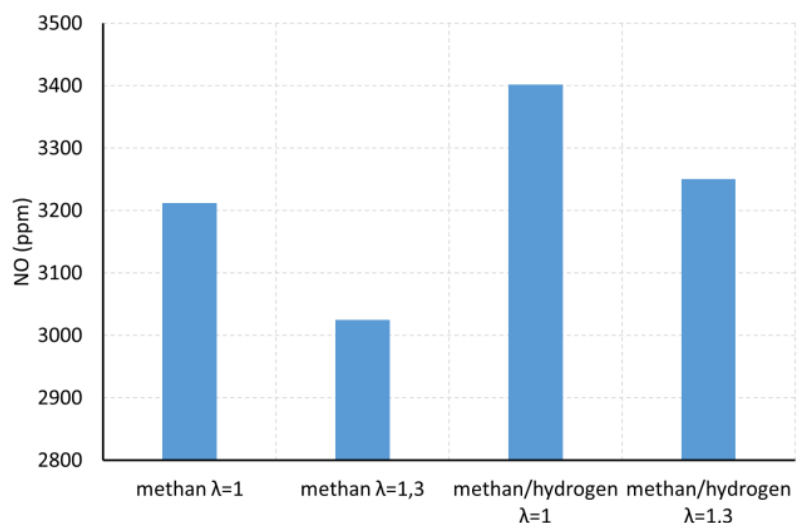

Fig. 7. NO emission as a function of excess air ratio (methane and methane/hydrogen)

As can be seen in figure 7 with increase in hydrogen and decrease in excess air ratio the emission of NO is increasing. This behavior is related with excess air ratio and hydrogen addition and caused by higher maximum temperature during combustion.

Figure 8 present emission of $\mathrm{HC}$. In case of $\mathrm{HC}$ emission with in-crease of excess air ratio and addition of hydrogen, the emission is decreasing.

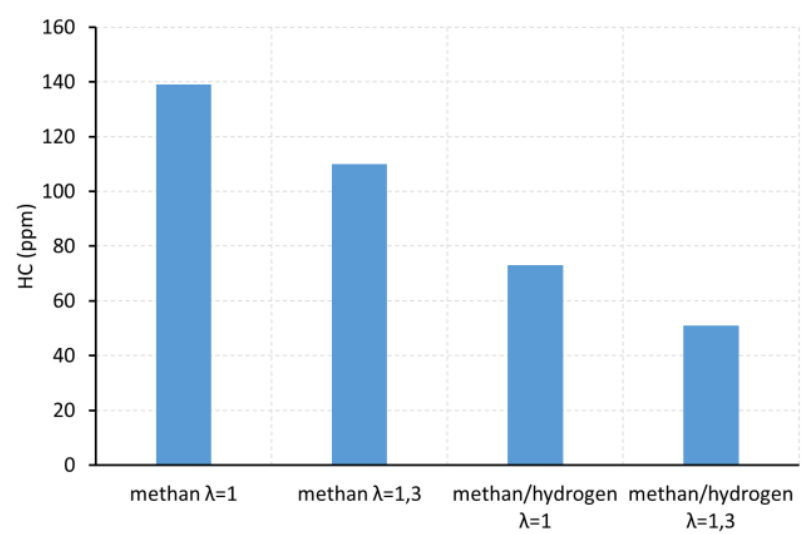

Fig. 8. $\mathrm{HC}$ emission as a function of excess air ratio (methane and methane/hydrogen)

This trend is caused by lowering the amount of carbon in fuel, first by leaner mixture, secound by hydrogen addition.

In figure $9 \mathrm{CO}$ emission can be observed. In case of $\mathrm{CO}$ emission the most impact for it emission has amount of carbon in fuel and excess air ratio. In case of $\mathrm{CO}$ emission with increase in ecxess air ration the decreas of thie component is observed. Additional decrease of $\mathrm{CO}$ is achieved by addidng the hydrogen. As a result for excess air ratio of 1,3 with hydrogen the lowest emission of $\mathrm{CO}$ was observed.

Figure 10 presents emission of $\mathrm{CO}_{2}$. Emission for this componet show similar trend as for $\mathrm{CO}$. Both factors as increase in excess air ratio and increase in hydrogen content in fuel mixture cause decrease in emission of $\mathrm{CO}_{2}$. That fact is releted with decreasing in carbon content in base fuel which was methane by addidng $30 \%$ of hydrogen and also decrease in amount of methane which fueled engine by increase in excess air rato.

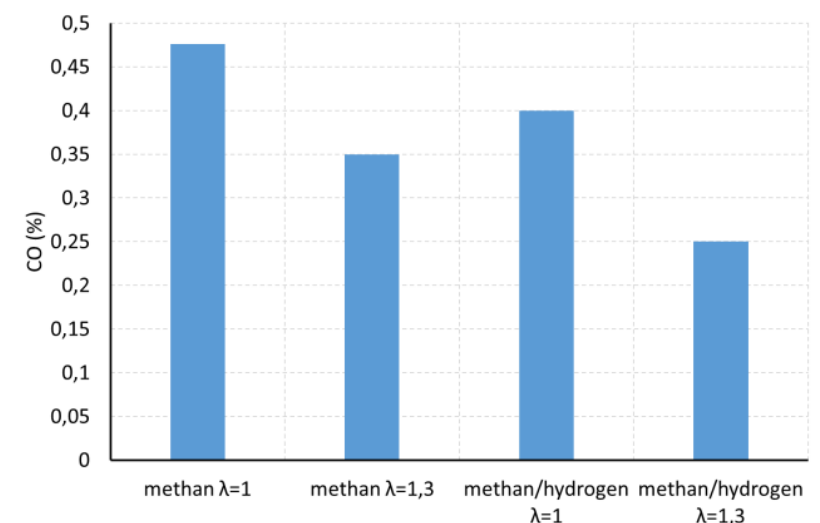

Fig. 9. $\mathrm{CO}$ emission as a function of excess air ratio (methane and methane/hydrogen)

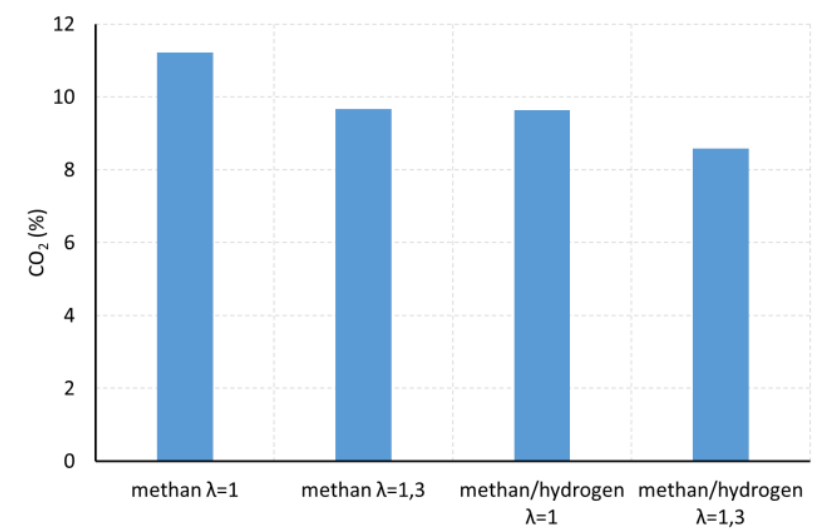

Fig. 9. $\mathrm{CO}_{2}$ emission as a function of excess air ratio (methane and methane/hydrogen)

\section{Conclusions}

The obtained results of the research allowed to present some conclusions as follows:

1. Addition of hydrogen to the base fuel require modifica-tion of ignition timing, it should be retarded, to obtaine optimal engine performance.

2. Addition of hydrogen to the methane cause increase in maximum pressure, what has influance for maximum temperature of combustion.

3. Increase in excess air ratio cause extended combustion for methane but for mixture of methane and hydrogen the combustion phase for both excess air ratio was nearly the same.

4. Methane/hydrogen mixture cause increase in NO emis-sion what is a result of higher temperature of combus-tion than for pure metane.

5. $\mathrm{CO}$ emission in all cases decreased what is caused by in-creas in excess air ratio and change in $\mathrm{H} / \mathrm{C}$ ratio.

6. $\mathrm{CO} 2$ emission is decreasing with increase in excess air ratio and $\mathrm{H} / \mathrm{C}$ ratio.

7. Addition of hydrogen lead to decrease in $\mathrm{HC}$ emission.

To sumarizethe results it can be said that addition of hydrogen to hydrocarbon fuel can be a promessing methode for limitation an exhaust gas emission from internal combustion engine.

\section{Acknolegements}

The research was done within the project under no. BS/MN 1103-303/2017/P financed by Czestochowa University of Technology 
Bibliografia:

1. Abbott M., The Economics of the Gas Supply Industry, Taylor \& Francis Limited, Nowy Jork, 2016, s. 185. ISBN 9781138998797.

2. Changwei J., Shuofeng W., Effect of hydrogen addition on combustion and emissions performance of a spark ignition gasoline engine at lean conditions, International journal of hydrogen energy 34 ( 2009 ) $7823-7834$

3. Grab-Rogaliński K., Szwaja S.:Combustion of Biomethane in an IC Engine with Over-Expanded Cycle, 2017 International Conference on Green Energy and Applications ICGEA2017, Nanayang Technological University, Singapore 25-27 March, p.148-152, 2017

4. Grab-Rogaliński K., Szwaja S.: Miller cycle application to gaseous supercharged SI engine, Combustion engines Vol. 3, pp. 881-885, 2015

5. Kahramana E, Ozcanlıb S. C., Ozerdemb B., An experimenta study on performance and emission characteristics of a hydrogen fuelled spark ignition engine, International Journal of Hydrogen Energy 32 (2007) 2066 - 2072

6. Karim G. A., Hydrogen as a spark ignition engine fuel, International Journal of Hydrogen Energy 28 (2003) 569 - 577

7. Kaye G.W.C.,Laby T.H., Tables of Physical and Chemical Constants and Some Mathematical Functions (16th Edition 1995), Longman Sc \& Tech, Harlow, 1995, ISBN 978-0582226296

8. Nande, A., Szwaja, S., and Naber, J., "Impact of EGR on Combustion Processes in a Hydrogen Fuelled SI Engine," SAE Technical Paper 2008-01-1039, 2008, https://doi.org/10.4271/2008-01-1039
9. Szwaja S., Grab-Rogaliński K.: Hydrogen combustion in a compression ignition diesel engine. International Journal of Hydrogen Energy Vol. 34 nr 10, 2009

10. https://dzikiezycie.pl/archiwum/2014/czerwiec-2014/stezenieco2-jak-zmienialo-sie-na-przestrzeni-wiekow

Wpływ dodatku wodoru na emisję toksycznych składników spalin w gazowym silniku spalinowym o zapłonie iskrowym

Jednym z głównych problemów silników spalinowych jest emisja toksycznych składników spalin. Zanieczyszczenia te są nie tylko szkodliwe dla środowiska ale również dla człowieka. Do obniżenia emisji toksycznych składników spalin wykorzystuje się w silnikach spalinowych wiele mechanicznych i chemcznych metod między innymi katalizatory trójdrożne, filtry cząstek stałych oraz katalizatory selekcyjne. Alternatywną metodą obniżenia emisji toksycznych składników spalin jest wykorzystanie paliwa alternatywnego jako nośnika energi lub jako dodatku do paliwa węglowodorowego. Prezentowany artykuł przedstawia wykorzystanie wodoru jako dodatku do paliwa podstawowego jakim był metan. Paliwa podawane były do kolektora dolotowego Procentowy stosunek objętościowy dla badanych paliw był następujacy 100/0 metan/wodór i 70/30 metan/wodór. Prowadzone pomiary wykazały, że dodatek wodoru do paliwa podstawowego wykazał spadek w emisji toksycznych składników spalin oraz wzrost parametrów urzytkowych silnika.

Słowa kluczowe: Silnik Zi, wodór, metan, emisje.

Author:

PhD Karol Grab-Rogaliński - Czestochowa University of Technology, Departament of Mechanical Engineering and Computer Science, Institute of Thermal Machines, e-mail: grab@imc.pcz.pl 